\title{
EFFECTS OF BELLY DANCING ON BODY IMAGE AND SELF- ESTEEM IN WOMEN WITH BREAST CANCER - PILOT STUDY
}

\author{
EFEITO DA DANÇA DO VENTRE NA IMAGEM CORPORAL E AUTOESTIMA DE MULHERES COM CÂNCER \\ DEMAMA - ESTUDOPILOTO
}

Original Article

ARTIGO ORIGINAL

Artículo Original

\author{
EFECTOS DE LA DANZA DEL VIENTRE EN LA IMAGEN CORPORAL Y AUTOESTIMA DEMUJERES CON \\ CÁNCERDEMAMA - ESTUDIO PILOTO
}

\begin{abstract}
Micheli Carminatti
(Physical Education Professional)

Leonessa Boing

(Physical Education Professional)

Bruna Leite 1

(Physiotherapist)

Fabiana Flores Sperandio

(Physiotherapist)

Thaina Korpalski

(Physical Education Professional)

Tatiana de Bem Fretta'

(Physiotherapist)

Melissa de Carvalho Souza Vieira (Physical Education Professional)

Alice Erwig Leitão'

(Physical Education Professional)

Jessica Moratelli

(Physical Education Professional)

Danielly Yani Fausto

(Physical Education Professional)

Juliana Araujo Klen ${ }^{1}$

(Physical Education Professional)

Adriana Coutinho de Azevedo

Guimarães $^{1}$

(Physical Education Professional)
\end{abstract}

1. Universidade do Estado de Santa Catarina, Florianópolis, SC, Brazil.

\section{Correspondence:}

Leonessa Boing

Rua General Estilac Leal, 260,

apto 105 bl B, Coqueiros,

Florianópolis, SC, Brazil. 88080-760.

leonessaboing@gmail.com

\begin{abstract}
Introduction: Breast cancer has innumerable consequences in women's lives and physical activity can be beneficial during this period. Objectives: To analyze the influence of belly dancing on the body image and selfesteem of women during and after breast cancer treatment. Methods: Nineteen women diagnosed with breast cancer, divided into a control group (8 women) and a study group (11 women), who were under treatment or post-treatment at the Center for Oncological Research (CEPON), participated in the study. A questionnaire was used for data collection, divided into three blocks as follows: a) general information - sociodemographic and clinical characterization; b) body image - Body Image After Breast Cancer; and c) self-esteem - Rosenberg Self-Esteem Scale. The study group underwent a belly dance intervention consisting of 60-minute classes, twice a week, for a total period of 12 weeks. Women in the control group only maintained their routine activities. Results: Significant changes were observed in the improvement of body image in the belly dance group in the pre- and post-intervention periods in the body stigma $(p=0.017)$ and transparency $(p=0.021)$ scales. There were no changes in regards to self-esteem. The control group had no changes in either body image or self-esteem. Conclusion: The influence of belly dancing on the improvement of women's body image was observed after 12 weeks of intervention. Thus, it is understood that physical activity may help these women after breast cancer, and should be encouraged by health professionals in this field. Level of evidence ll; Therapeutic studies - Investigation of treatment results.
\end{abstract}

Keywords: Breast neoplasms; Dance; Quality of life; Body image; Self concept.

\section{RESUMO}

Introdução: O câncer de mama traz inúmeras consequências para a vida das mulheres e a a tividade física pode ser benéfica neste período. Objetivos: Analisar a influência da dança do ventre na imagem corporal e autoestima das mulheres durante e após o tratamento do câncer de mama. Métodos: Participaram do estudo 19 mulheres, divididas em grupo controle (oito mulheres) e grupo experimental (11 mulheres), diagnosticadas com câncer de mama em tratamento ou após o-tratamento no Centro de Pesquisas Oncológicas (CEPON). Para a coleta de dados, utilizou-se um questionário dividido em três blocos: a) informações gerais - caracterização sociodemográfica e clínica; b) imagem corporal -Body Image After Breast Cancer; ec) autoestima - Escala de Autoestima de Rosenberg. O grupo experimental foi submetido a uma intervenção com aulas de 60 minutos de dança do ventre, duas vezes por semana, por um período total de 12 semanas. O grupo controle apenas manteve suas atividades de rotina. Resultados: Houve mudanças significativas na melhora da imagem corporal no período pré-e pós-intervenção do grupo experimental, nas escalas de estigma corporal $(p=0,017)$ e transparência $(p=0,021)$. Não houve modificações em relação à autoestima. O grupo controle não apresentou mudanças tanto na imagem corporal quanto na autoestima. Conclusão: Percebeu-se a influência da dança do ventre na melhora da imagem corporal das mulheres após 12 semanas de intervenção. Dessa maneira, entende-se que a prática de uma atividade física pode auxiliar essas mulheres após o câncer de mama e deve ser incentivada por profissionais de saúde desta área. Nível de evidência ll; Estudos terapêuticos-Investigação dos resultados do tratamento.

Descritores: Neoplasias da mama; Dança; Qualidade de vida; Imagem corporal; Autoestima.

\section{RESUMEN}

Introducción: El cáncer de mama trae innumerables consecuencias para la vida de las mujeres y la actividad física puede ser beneficiosa en este período. Objetivos: Analizar la influencia de la danza del vientre en la imagen corporal y la autoestima de las mujeres durante y después del tratamiento del cáncer de mama. Métodos: Participaron del estudio 19 mujeres, divididas en grupo control (ocho mujeres) y grupo experimental (11 mujeres), diagnosticadas con cáncer de mama en tratamiento o post tratamiento en el Centro de Investigaciones Oncológicas (CEPON). Para la recolección de los datos se utilizó un cuestionario dividido en tres bloques: a) informaciones generales - caracterización sociodemográfica y clínica; b) imagen corporal - Body Image After Breast Cancer; y c) autoestima - Escala de Autoestima de Rosenberg. El grupo experimental fue sometido a una intervención con clases de 60 minutos de danza del 
vientre, dos veces por semana, por un período total de 12 semanas. El grupo control sólo mantuvo sus actividades de rutina. Resultados: Hubo cambios significativos en la mejora de la imagen corporal del período pre y post intervención del grupo experimental, en las escalas de estigma corporal ( $p=0,017)$ y transparencia $(p=0,021)$. En la autoestima no se encontraron modificaciones. El grupo control no presentó cambios, tanto en la imagen corporal, como en la autoestima. Conclusión: Se percibió la influencia de la danza del vientre en la mejora de la imagen corporal de las mujeres después de las 12 semanas de intervención. De esta manera, se entiende que la práctica de una actividad física puede ayudar a esas mujeres después del cáncer de mama, y debe ser incentivada por profesionales de salud de esta área. Nivel de evidencia II; Estudios terapéuticos-Investigación de los resultados del tratamiento.

\section{Descriptores: Neoplasias de la mama; Baile; Calidad de vida; Imagen corporal; Autoestima.}

\section{INTRODUCTION}

Breast cancer is the second most common type of cancer worldwide, with an estimated 2.1 million cases, corresponding to $11.6 \%$ of all diagnosed cancers ${ }^{1}$. According to the José de Alencar National Cancer Institute, in Brazil, 59,700 new cases are estimated for the 2018/2019 biennium, with an estimated risk of 56.33 cases per 100,000 women².

Breast cancer is currently treated as a systemic disease and surgical treatment is therefore followed by an adjuvant therapy such as chemotherapy, radiotherapy or hormone therapy ${ }^{3}$. Facing breast cancer can cause changes in body image, functional loss, and psychological trauma in the woman ${ }^{4,5}$.

Within this context, physical activity becomes important to reduce these consequences in the life of women after the diagnosis of breast cancer both as a prevention factor and for health promotion to reduce the side effects of treatment ${ }^{6,7}$. One type of physical activity that can be included in this process is dancing, which is an important tool for maintaining a healthy life since it provides good physical conditioning and helps in the development of physical capacities ${ }^{8}$.

A systematic review investigated dance as a physical activity in women with breast cancer and found this activity to be associated with psychological and physical benefits, with different dance modalities such as dance therapy, ballroom dance, circle dance, jazz and classical ballet ${ }^{9}$. On the other hand, belly dance as a modality was only investigated by Boing et al. ${ }^{10}$ who found positive effects on quality of life, depressive symptoms, and fatigue. Body image and self-esteem, which can be severely altered after the diagnosis of breast cancer, have not been explored in women participating in belly dance. Therefore, the aim of this pilot study was to analyze the effects of belly dance on the body image and self-esteem of women with breast cancer.

\section{METHODOLOGICAL PROCEDURES}

Nineteen women (54.55 \pm 8.29 years), divided into a control group (CG; $n=8)$ and a study group ( $S G ; n=11$ ), participated in this non-randomized clinical trial pilot study. Data of this project have been published previously by Boing et al. ${ }^{10}$ The minimum sample size was 11 women per group (SG and CG). Adherence to the belly dance classes among women of SG was $78.6 \%$ (95\%Cl: 71.3-85.9).

The criteria for inclusion were a) age between 40 and 80 years, and b) undergoing any phase of adjuvant or neoadjuvant treatment at the Center for Oncological Research (CEPON) since the study for composing the database was conducted at this institution or undergoing follow-up after the end of clinical treatment. Excluded were illiterate women because of the need for understanding the study questions and women with stage IV disease in order to avoid bias in the type of treatment and prognosis.

The participants were selected from the database of a cross-sectional project entitled "Physical activity, quality of life and associated factors in women after the diagnosis of breast cancer", conducted by the researchers at CEPON. Details of the sample selection can be found in Boing et al. ${ }^{10}$ according to Figure 1 .

For CG, 11 women who were not willing to participate in the intervention but were interested in participating in the study were initially selected. The women were asked to maintain their habitual physical activity since most of them were considered insufficiently active (data not shown in the table). In SG, three women, respectively, withdrew from the activities because of the following reasons: diagnosis of stage IV disease, physical indisposition due to chemotherapy, and lack of financial resources for transportation. Thus, only eight women completed the intervention.

The data were collected with a questionnaire applied during individual interviews divided into three steps:

1. General information including age, marital status, education level, presence of diseases, type of breast cancer treatment, time of first diagnosis, concomitant medication, anthropometric measurements, and socioeconomic status. This step has been described in detail in the previously published study involving the same patients ${ }^{10}$.

2. Body image was evaluated using the Body Image After Breast Cancer Questionnaire, which was translated, validated and culturally adapted for the Brazilian population ${ }^{11}$. The instrument consists of six scales (vulnerability, body stigma, limitation, body concerns, transparency, and arm problems). For each scale, the higher the score, the poorer the body image.

3. Self-esteem was evaluated using the Rosenberg Self-Esteem Scale ${ }^{12}$. This instrument is a one-dimensional measure consisting of 10 statements related to a set of feelings of self-worth and self-acceptance that assess overall self-esteem. The final score can range from 10 to 40, with a higher score indicating better self-esteem of the patient. The scale was validated for the population with breast cancer ${ }^{13}$.

The study was approved by the Ethics Committees of the State University of Santa Catarina (UDESC) (Approval No. 688.548) and of CEPON (Approval No. 818.174). The researchers collected the data at the Center for Health and Sports Sciences (CEFID) of UDESC before and after the intervention by application of a structured questionnaire on scheduled days and times. Data collection lasted approximately 30 minutes in SG and CG. Patients who were interested in participating in the study signed the free informed consent form.

The dance classes were held in the gym of CEFID/UDESC twice a week in the afternoon, with a duration of 60 minutes/class, for a period of 12 weeks. Belly dance was selected for the intervention because it develops the intimate relationship between movement and emotion, triggering a spontaneous body language that focuses on free movements inherent to each practitioner by rescuing feminine identity and because it intensely exercises the upper limbs.

The classes were applied in the following order: 1) Warm-up and initial stretching for 10 minutes. The exercises were guided by the teacher using 


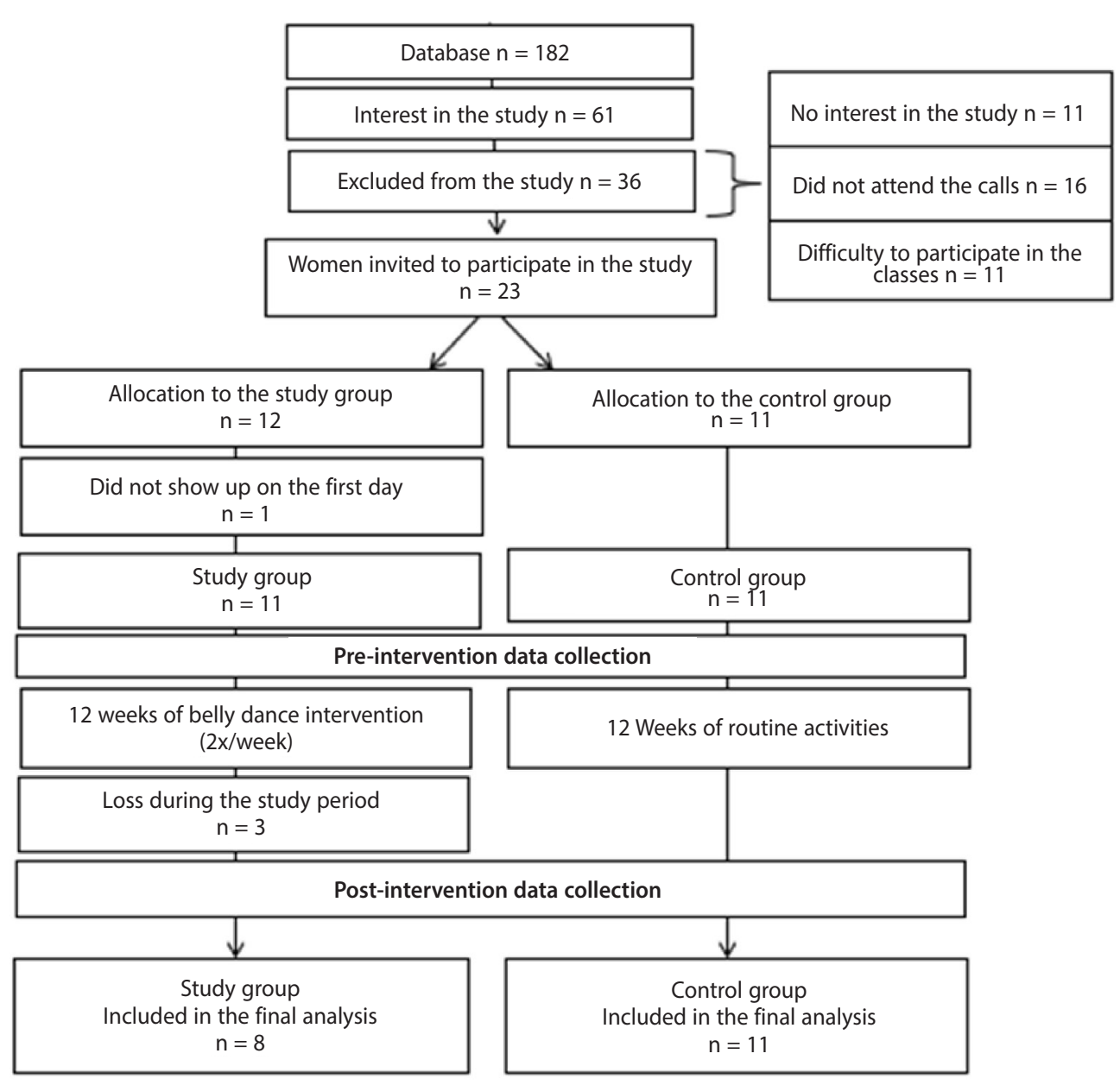

Figura 1. Flow diagram showing the selection of the study and control groups through each stage of the study: enrollment, allocation and exposure to the intervention, follow-up, and analysis ${ }^{10}$.

broad joint movements starting in the upper part of the body until reaching the lower limbs. 2) Main part: brief explanations about the theory of belly dance or a specific step, followed by practical teaching of the movement. The aim of this phase was to develop belly dance movements by stimulating motor coordination, rhythm and body consciousness, improving flexibility and range of motion of the upper limb. The movements were explored in an individual dynamic manner in pairs or groups and consisted of the participants moving according to the rhythm of the music, with the freedom of creating their own movement pattern based on body consciousness and permitting the expression of feelings. The technique evolved according to the progression of the students in memorizing and understanding the specific movement as described in detail in the study of Boing et al. (2017) ${ }^{10}$. (3) Relaxation: The class was finished with a brief conversation about each student's perception of the class and whether the initially established goals were achieved.

The data were analyzed using the IBM SPSS 20.0 package. Two-way ANOVA for repeated measures and the Sidak comparison test were used for analysis of SG and CG pre- and post-intervention.

\section{RESULTS}

The general and clinical characteristics of the women in the two groups have been reported in the study of Boing et al. (2017) ${ }^{10}$. It should be noted that there was no significant difference in the pre-intervention variables between groups, except for current occupation ( $p=0.002)$. Most women of SG were housewives, while most women of CG were retired, unemployed, or medical leave.
Table 1 shows the comparison of body image and self-esteem data between SG and CG pre- and post-intervention. Significant differences in the body image variables were only observed between pre- and post-intervention in SG for body stigma $(p=0.017)$ and transparency $(p=0.021)$. There was no difference in self-esteem pre- and post-intervention in either group, nor between SG and CG post-intervention.

\section{DISCUSSION}

The main objective of the study was to analyze the effects of belly dance on the body image and self-esteem of women undergoing breast cancer treatment or post-treatment. Improvement in body image was

Table 1. Comparison of body image and self-esteem between the study and control groups of women after breast cancer diagnosis pre- and post-belly dance intervention. Florianópolis, SC, 2015 ( $n=19)$

\begin{tabular}{|c|c|c|c|c|c|c|c|}
\hline \multirow[t]{2}{*}{ Variable } & \multicolumn{2}{|c|}{$\begin{array}{c}\text { SG } \\
\times(S D)\end{array}$} & \multirow[b]{2}{*}{$p^{*}$} & \multicolumn{2}{|c|}{$\begin{array}{c}\text { CG } \\
\times(S D)\end{array}$} & \multirow[b]{2}{*}{$p^{* *}$} & \multirow{2}{*}{$\begin{array}{l}\text { Post } \\
p^{\#}\end{array}$} \\
\hline & Pre & Post & & Pre & Post & & \\
\hline \multicolumn{8}{|l|}{ Body image } \\
\hline Vulnerability & $25 \pm 2$ & $21 \pm 2$ & 0.197 & $20 \pm 2$ & $23 \pm 1$ & 0.234 & 0.528 \\
\hline Body stigma & $38 \pm 3$ & $31 \pm 2$ & 0.017 & $27 \pm 3$ & $27 \pm 2$ & 0.835 & 0.303 \\
\hline Transparency & $14 \pm 2$ & $10 \pm 1$ & 0.021 & $10 \pm 1$ & $11 \pm 1$ & 0.670 & 0.795 \\
\hline Body concerns & $20 \pm 2$ & $18 \pm 2$ & 0.377 & $14 \pm 1$ & $16 \pm 1$ & 0.670 & 0.572 \\
\hline Arm problems & $10 \pm 1$ & $8 \pm 0$ & 0.179 & $8 \pm 1$ & $8 \pm 0$ & 0.801 & 0.961 \\
\hline Limitations & $18 \pm 2$ & $16 \pm 1$ & 0.400 & $16 \pm 2$ & $15 \pm 1$ & 0.532 & 0.512 \\
\hline Self-esteem & $29 \pm 1$ & $32 \pm 2$ & 0.075 & $32 \pm 1$ & $32 \pm 1$ & 0.711 & 0.822 \\
\hline
\end{tabular}

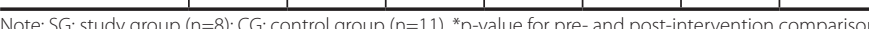
in SG.** $\mathrm{p}$-value for pre- and post-intervention comparison in CG. "p-value for comparison between SG and CG post-intervention. Two-way ANOVA for repeated measures and Sidak comparison test. 
observed in SG after 12 weeks of intervention, while no significant differences were found in self-esteem.

The results of analysis of the influence of belly dance on body image were significant for the body stigma and transparency scales. Regarding stigma, breast cancer causes intense suffering in the woman who blocks her feelings, faces a constant loss of identity, and experiences situations of prejudice about the disease ${ }^{14}$. The breast plays a very important role in feminine identity and is valued by society, which determines the ideal body model for women. Hence, the female body is always being evaluated and judged ${ }^{15}$. For women, their body is understood as a vehicle for communicating with the world, something that refers to the feeling of being a woman ${ }^{16}$. Thus, belly dance broadly explores a woman's femininity, developing self-acceptance and stimulating creativity.

Women with breast cancer suffer from the consequences of treatment and often isolate themselves because of their body image caused by mastectomy and hair loss ${ }^{15}$, thus highlighting the importance of the dance classes for improving body stigma and transparency. The exercises were performed in front of a mirror so that the women were required to look at themselves and perceive their body, a fact that may have contributed to improving transparency, which refers to the acceptance of changes caused by cancer.

Women who underwent surgery for breast cancer may experience greater suffering and anguish because of the bodily changes, which lead to social isolation ${ }^{17,18}$. Within this context, the present results showing improvement in the body image of these women after the belly dance classes may help improve socialization with relatives, partners and friends. In the belly dance technique, the costumes play several roles; for example, the coins around the hips serve as a guide to know whether the movement is performed correctly. In addition, the feeling of being part of a fantasy helps the woman distance herself to indulge in the movements without fear or shame of herself or others ${ }^{19}$. It is through the movement and experimentation of the body that the individual recognizes and builds her body image ${ }^{20}$. Dancing explores the body, allowing the integration of physical health through movements, as well as socialization that occurs in the classroom ${ }^{21}$. This fact may have influenced the results of the body stigma scale, minimizing the shame about the own body by wearing the belly dance costumes and by performing feminine movements during the activity.

The belly dance classes were held twice a week, for a total of 120 minutes. However, for additional health benefits, cancer patients should increase aerobic activity of moderate intensity to 150 minutes per week or of vigorous intensity to 75 minutes or should perform an equivalent combination of moderate and vigorous activity ${ }^{22}$. Increasing the duration of the classes during the week may provide greater benefits for these women. On the other hand, since this was a pilot study, new randomized clinical trials could satisfy these expanded recommendations.

The spontaneous reports during the classes showed an increasingly positive relationship between body and mind, personal growth, relaxation, and spirituality. Physical activity promotes an increase in well-being, improvement of movement, greater body appreciation, and the construction of positive memories and experiences ${ }^{23}$. Belly dance is essentially feminine and the fact that these experiences occurred in an environment involving only women was important, as they shared the same experience. This may have somehow promoted comfort and encouragement to perceive that it is possible to overcome such situations.

Other dance modalities as therapy for breast cancer have been reported in the literature. In one of the first studies investigating classical ballet and jazz ${ }^{24}$, the patients reported a modified and healthy view about their body image and feelings of femininity as a result of sensuality, in agreement with the findings of the present study. Dance therapy is widely investigated in breast cancer patients, ${ }^{23,25-27}$ and particularly provides psychological benefits, with feelings of freedom and joy resulting from dancing. Greek traditional dances combined with upper body training resulted in an increase of life satisfaction and a decrease of depressive symptoms in breast cancer patients ${ }^{28}$. Regarding benefits for quality of life, circle dance ${ }^{29}$ and ballroom dance ${ }^{30}$ also showed positive effects. These results demonstrate that other dance modalities can also be beneficial for breast cancer patients and, like belly dance, should be encouraged.

The present study found no significant influence of belly dance on the self-esteem of women; however, the values increased in women of SG. In addition, the spontaneous reports regarding this variable were always positive. The lack of a significant difference may have been due to the program duration of only 12 weeks. During this period, the women had to become familiar with the new modality, with the class location, and with colleagues and the teacher. In addition, the number of women was small.

The study has some limitations such as the fact that it was not randomized. However, the aim was to offer all women the opportunity to participate in the intervention since it was a pilot study. Consequently, women who decided to participate in the intervention may have had a greater prior expectation and predisposition to better results than women of CG. Another limitation was the sample loss. Since the women were still clinically treated for breast cancer, receiving chemotherapy, radiotherapy or hormone therapy, some absences and dropouts were inevitable because of the intense side effects of the treatments.

\section{CONCLUSION}

The effects of belly dance on the body image of women participating in the study were demonstrated for the body stigma and transparency scales after 12 weeks of intervention. The benefits of this activity were also observed by the spontaneous reports during the classes, with improvement of femininity and confidence. Randomized clinical trials are necessary to investigate psychological and physical issues related to cancer and to strengthen the findings on belly dance in women with breast cancer.

All authors declare no potential conflict of interest related to this article

AUTHORS' CONTRIBUTIONS: Each author made significant individual contributions to this manuscript. MC (ORCID: 0000-0001-8926-8211)*, LB (0000-0003-4978-9703)* and ACAG (0000-0001-5167-2921)* responsible for the conception, design, data collection, data analysis and interpretation, writing of the manuscript, and approval of the version submitted BL (0000-0002-7454-7987)*, FFS (0000-0002-2435-0246)*, TK (0000-0002-5438-5458)*, TBF (0000-0002-9735-3472)*, MCSV (0000-0002-7861-7620), AEL (0000-0002-1169-6686), JM (0000-0003-2007-4552), DYF (0000-0001-5382-7878), JAK (0000-0001-9255-0664) contributed to the data collection, writing of the manuscript, and approval of the version submit-ted. *ORCID (Open Researcher and Contributor ID).

\section{REFERENCES}

1. International Agency for Research on Cancer - World Health Organization. GLOBOCAN - Global Cancer Observatory. [Acesso em 04 nov. 2018] Disponível em: <http://gco.iarc.fr/>

2. Instituto Nacional de Câncer - INCA. Estimativa 2018: Incidência de câncer no Brasil. 2018. [Acesso em:?] Disponível em <http://www.inca.gov.br/estimativa/2018/>

3. Makluf ASD, Dias RC, Barra ADA. Avaliação da qualidade de vida em mulheres com câncer de mama. Rev Bras Cancerol. 2006;52(1):49-58.
4. Soares WTE. Parâmetros, Considerações e Modulação de Programas de Exercício Físico para Pacientes Oncológicos - Uma Revisão Sistemática. Rev Bras Ciênc Esporte. 2011;17(4):284-9.

5. Inumaru LE, Silveira EA, Naves MMV. Fatores de risco e de prevenção para câncer de mama: uma revisão sistemática. Cad Saúde Pública. 2011;27(7):1259-70.

6. Matsudo SM. Atividade física na promoção da saúde e qualidade de vida no envelhecimento. Rev Bras Educ Fís. 2006;20(1):135-7. 
7. Battaglini C, Bottaro M, Dennehy C, Barfoot D, Shields E, Kirk D, et al. Efeitos do treinamento de resistência na força muscular e níveis de fadiga em pacientes com câncer de mama. Rev Bras Med Esporte. 2006;12(3):153-8

8. Castro Filha JGL, Miranda AKP, Martins Junior FF, Costa HA, Figueiredo KRFV, de Oliveira Junior MNS, et al. Influências do Exercício físico na qualidade de vida em dois grupos de pacientes com câncer de mama. Rev Bras Ciênc Esporte. 2016;38(2):107-14.

9. Boing L, Rafael AD, Braga HO, Moraes AJP, Sperandio FF, Guimarães ACA. Dance as treatment therapy in breast cancer patients - a systematic review. Rev Bras Ativ Fís Saúde. 2017;22(4):319-31.

10. Boing L, Baptista MFM, Pereira GS, Sperandio FF, Moratelli J, Cardoso A, et al. Benefits of belly dance on quality of life, fatigue, and depressive symptoms in women with breast cancer - A pilot study of a non-randomised clinical trial. J Bodyw Mov Ther. 2018;22(2):460-6.

11. Gonçalves CO, Tavares MCG, Campana ANNB, Cabello C. Validation of the instrument "Body image after breast cancer" in Brazil. Motriz: Rev Educ Fis. 2014;20(1):8-15.

12. Curbow B, Somerfield M. Use of the Rosenberg Self-Esteem Scale with Adult Cancer Patients. J Psychosoc Oncol. 1991;9(2):113-31.

13. Rêgo IKP, Nery IS. Acesso e adesão ao tratamento de mulheres com câncer de mama assistidas em um hospital de oncologia. Rev Bras Cancerol. 2013;59(3):379-90.

14. Fang SY, Chiu SC, Shu BC. The experience of women after breast cancer mastectomy: objectification theory perspective. Hu Li Za Zhi. 2011;58(4):75-80.

15. Prates ACL, Freitas RJ, Prates MFO, Veloso MF, Barros NM. Influence of Body Image in Women Undergoing Treatment for Breast Cancer. Rev Bras Ginecol Obstet. 2017;39(4):175-83.

16. Santos DB, Vieira EM. Imagem corporal de mulheres com câncer de mama: uma revisão sistemática da literatura. Ciênc Saúde Coletiva. 2011;16(5):2511-22.

17. Enomoto SM, Pires IAL, Rizzi SKLA, Haddad CAS, Nazário ACP, Facina G. Avaliação da imagem corporal e da função sexual em mulheres com linfedema após tratamento cirúrgico de câncer de mama. Rev Bras de Mast. 2014;24(1):9-16.

18. Bencardini P. Dança do Ventre: Ciência e Arte. São Paulo: Baraúna Editora; 2002.
19. Turtelli LS. Relações entre imagem corporal e qualidade de movimento: uma reflexão a partir de uma pesquisa bibliográfica. Dissertação de mestrado. Universidade Estadual de Campinas. 2000.

20. Abrão AC, Pedrão LJ. A Contribuição da dança do ventre para a educação corporal, saúde física e mental de mulheres que frequentam uma academia de ginástica e dança. Rev Lat Am Enfermagem. 2005;13(2):243-8.

21. Mannheima EG, Helmesb A, Weis J. Tanztherapie in der stationären onkologischen Rehabilitation. Forsch Komplementmed. 2013;20(1):33-41.

22. World Health Organization - WHO. Global Health Estimates: Breast Cancer. 2017. [Acesso em?] Disponível em http://www.who.int/dietphysicalactivity/physical-activity-recommendations-18-64years.pdf

23. Ho RTH, Fong TCT, Cheung IKM, Yip PSF, Luk M. Effects of a short-term dance movement therapy program on symptoms and stress in patients with breast cancer undergoing radiotherapy: a randomized, controlled, single-blind trial. J Pain Symptom Manage. 2016;51(5):824-83.

24. Molinaro J, Kleinfelt M, Lebed S. Physical Therapy and Dance in the Surgical Management of Breast Cancer: A clinical report. Phys Ther. 1986;66(6):967-9.

25. Crane-Okada R, Kiger H, Sugerman F, Uman GC, Shapiro SL, Wyman-McGinty W, et al. Mindful movement program for older breast cancer survivors-a pilot study. Cancer Nurs. 2012;35(4):E1-13.

26. Blázquez A, Nierga J, Javierre C. Terapia a través de la danza y el movimiento en mujeres con cáncer de mama: el impacto psicofísico del proceso empático. Psicooncología. 2011;8(1):31-43.

27. Sandel S, Judge JO, Landry N, Faria L, Ouellete R, Majczak M. Dance and movement program improves quality-of-life measures in breast cancer survivors. Cancer Nurs. 2005;28(4):301-9.

28. Kaltsatou A, Mameletzi D, Douka S. Physical and psychological benefits of a 24-week traditional dance program in breast cancer survivors. J Bodyw Mov Ther. 2011;15(2):162-7.

29. Frison FS, Shimo KK, Gabriel M. Sacred dance and quality of life in women mastectomy: a pilot study. Saúde Debate. 2014;38(101):277-84.

30. Pisu M, Demark-Wahnefried W, Kenzik KM, Oster RA, Lin CP, Manne S, et al. A dance intervention for cancer survivors and their partners (RHYTHM). J Cancer Surviv. 2017;11(3):350-9. 


\section{ERRATUM \\ ERRATA \\ ERRATA}

In the article entitled "EFFECTS OF BELLY DANCING ON BODY IMAGE AND SELF-ESTEEM IN WOMEN WITH BREAST CANCER - PILOT STUDY" authored by Micheli Carminatti, Leonessa Boing, Bruna Leite, Fabiana Flores Sperandio, Thaina Korpalski, Tatiana de Bem Fretta, Adriana Coutinho de Azevedo Guimarães, published in Rev Bras Med Esporte vol.25 n 6, 2020, page 464, DOI http://dx.doi.org/10.1590/1517-869220192506220067, by request of the authors:

Where it reads:

Micheli Carminatti ${ }^{1}$

(Physical Education Professional)

Leonessa Boing ${ }^{1}$

(Physical Education Professional)

Bruna Leite

(Physiotherapist)

Fabiana Flores Sperandio

(Physiotherapist)

Thaina Korpalski ${ }^{1}$

(Physical Education Professional)

Tatiana de Bem Fretta

(Physiotherapist)

Adriana Coutinho de Azevedo Guimarães ${ }^{1}$

(Physical Education Professional)

1. Universidade do Estado de Santa Catarina, Florianópolis, SC, Brazil.

\section{Read:}

Micheli Carminatti'

(Physical Education Professional)

Leonessa Boing ${ }^{1}$

(Physical Education Professional)

Bruna Leite 1

(Physiotherapist)

Fabiana Flores Sperandio ${ }^{1}$

(Physiotherapist)

Thaina Korpalski ${ }^{1}$

(Physical Education Professional)

Tatiana de Bem Fretta'

(Physiotherapist)

Melissa de Carvalho Souza Vieira'

(Physical Education Professional)

Alice Erwig Leitão'

(Physical Education Professional)

Jessica Moratelli ${ }^{1}$

(Physical Education Professional)

Danielly Yani Fausto'

(Physical Education Professional)

Juliana Araujo Klen'

(Physical Education Professional)

Adriana Coutinho de Azevedo Guimarães ${ }^{1}$

(Physical Education Professional)

1. Universidade do Estado de Santa Catarina,

Florianópolis, SC, Brazil.

page 467

\section{Where it reads:}

AUTHORS' CONTRIBUTIONS: Each author made significant individual contributions to this manuscript. MC (ORCID: 0000-0001-8926-8211)*, LB (0000-0003-4978-9703)* and ACAG (0000-0001-5167-2921)* responsible for the conception, design, data collection, data analysis and interpretation, writing of the manuscript, and approval of the version submitted; BL (0000-0002-7454-7987)*, FFS (0000-0002-2435-0246)*, TK (0000-0002-5438-5458)*, TBF (0000-0002-9735-3472)* contributed to the data collection, writing of the manuscript, and approval of the version submitted. *ORCID (Open Researcher and Contributor ID).

\section{Read:}

AUTHORS' CONTRIBUTIONS: Each author made significant individual contributions to this manuscript. MC (ORCID: 0000-0001-8926-8211)*, LB (0000-0003-4978-9703)* and ACAG (0000-0001-5167-2921)* responsible for the conception, design, data collection, data analysis and interpretation, writing of the manuscript, and approval of the version submitted; BL (0000-0002-7454-7987)*, FFS (0000-0002-2435-0246)*, TK (0000-0002-5438-5458)*, TBF (0000-0002-9735-3472)*, MCSV (00000002-7861-7620), AEL (0000-0002-1169-6686), JM (0000-0003-2007-4552), DYF (0000-0001-5382-7878), JAK (0000-0001-9255-0664) contributed to the data collection, writing of the manuscript, and approval of the version submitted. 